\title{
$\underline{\text { O controle da natalidade: a sociedade em risco }}$
}

\author{
Fabíola Rohden
}

\section{SciELO Books / SciELO Livros / SciELO Libros}

ROHDEN, F. O controle da natalidade: a sociedade em risco. In.: A arte de enganar a natureza: contracepção, aborto e infanticídio no início do século XX [online]. Rio de Janeiro: Editora FIOCRUZ, 2003, pp. 89-121. História e saúde collection. ISBN: 978-65-5708-117-4. https://doi.org/10.7476/9786557081174.0005.

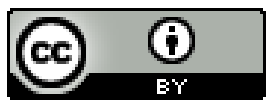

All the contents of this work, except where otherwise noted, is licensed under a Creative Commons Attribution 4.0 International license.

Todo o conteúdo deste trabalho, exceto quando houver ressalva, é publicado sob a licença Creative Commons Atribição 4.0.

Todo el contenido de esta obra, excepto donde se indique lo contrario, está bajo licencia de la licencia Creative Commons Reconocimento 4.0. 


\section{O controle da Natalidade:}

\section{a sociedade em rísco}

As discussões envolvendo aborto, infanticídio e a questão mais geral do controle da natalidade, longe de se circunscreverem ao domínio mais restrito da relação entre médico e paciente, se convertiam em grandes polêmicas públicas. Por um lado, envolviam toda a elite médica da época; por outro, atestavam o quanto os problemas visados pelos médicos em muito se distanciavam daqueles mais específicos tratados nos consultórios. Cada vez mais nossos doutores advogavam o direito de intervir nas questões que colocavam em xeque o próprio futuro da nação, e entre elas se destacava o crescimento da população.

As diferentes visões em torno desse tema mais amplo podem ser apreciadas a partir de alguns grandes debates ocorridos no meio médico do começo do século XX em instituições, como a Academia Nacional de Medicina, e eventos médicos importantes, como o Congresso Nacional de Práticos. O primeiro a ser tratado gira em torno do caso das mulheres belgas e francesas estupradas por soldados adversários durante a Primeira Guerra Mundial e do seu discutível direito ao aborto.

\section{O Caso das Mulheres Estupradas na Primeira Guerra}

A discussão sobre o aborto nas primeiras décadas do século XX estava muito longe de permanecer restrita às teses de medicina. Ocupava lugar de destaque também nas revistas especializadas e mesmo nos jornais de ampla circulação. Um exemplo paradigmático é a polêmica que se criou em 1915 em torno da possibilidade de direito ao aborto para as mulheres estupradas na guerra. A situação das francesas e belgas vítimas dos soldados alemães se transformou em um dos assuntos mais debatidos naquele 
ano. Tudo começou com a reprodução do debate público que se dava entre os médicos franceses sobre o assunto. A Revista Syniatrica descreve este início, em agosto de 1915:

A propósito das violências cometidas pela soldadesca alemã nas mulheres francesas e belgas, nos povoados invadidos durante a atual guerra européia, agitou-se a questão de ser ou não lícita a provocação do aborto para desembaraçar a mulher violentada do produto dessa concepção tão monstruosamente realizada.

A Presse Médicale, de Paris, formulou sobre essa tese especial de deontologia médica, um quesito que atirou à publicidade, apelando para a classe médica de todo o mundo, perguntando-lhe se é lícito provocar o aborto nas mulheres violadas na guerra. (Revista Syniatrica, 1915:117)

$O$ artigo nos informa ainda que muitas respostas pró e contra foram formuladas. No Brasil, o debate tomou fôlego depois que o então doutorando de medicina Leonídio Ribeiro publicou no jornal o Imparcial uma consulta, solicitando a opinião dos médicos a respeito. O assunto foi considerado tão relevante que as respostas obtidas foram lidas na Academia Nacional de Medicina. A Revista Syniatrica, nos números mensais entre agosto e dezembro de 1915, publicou as respostas mais interessantes ou formuladas pelos médicos mais eminentes. Transcrevo alguns trechos, pois este material é revelador sobre a percepção dos médicos a respeito do aborto.

O dr. Ernesto Nascimento e Silva afirma que provocar o aborto nas mulheres violadas na guerra seria um crime, um atentado contra a segurança da pessoa e da vida. E descreve a única possibilidade para a prática do aborto:

Ao médico, só e exclusivamente é lícita a provocação do aborto como um recurso de tratamento, isto é, é permitido praticar o denominado aborto terapêutico: operação salutar, ato científico do domínio da obstetrícia.

Ao aborto terapêutico, ainda que excepcional, às vezes indispensável, importa, porém, como justificação de sua legitimidade, que se verifique, criteriosamente, a sua exata e perfeita indicação no caso concreto, como a ultima ratio; e, dentro desses limites, restritos e bem discutidos, tal operação será - o aborto legal ou o aborto necessário - na expressão da letra do nosso código penal. (Revista Symiatrica, 1915:118)

O dr. Queiroz de Barros também é contra o aborto. Sua resposta tem a peculiaridade de transformar as mulheres violadas em mártires, mas 90 
não admite a interrupção da gravidez. Também toca na questão da honra, tão importante para a justiça nos casos de aborto e infanticídio, dizendo que a mulher estuprada não tem do que se envergonhar:

É tão pungente a angústia de quem traz em seu seio o imposto filho de um inimigo em armas contra a sua pátria, como o é o de um indivíduo a quem não ama; entretanto, ninguém ainda pensou em justificar o aborto neste caso.

Não perde a mulher do seu pudor nem macula a sua alma por um ato que não praticou. Sob a pressão da força tal como sob a ação do clorofórmio, o ato foi executado sem o seu consentimento, sem a sua cooperação moral, impossibilitada de fugir ou reagir. Penso que não é lícito provocar o aborto nas mulheres violadas na guerra; penso que elas devem ser assistidas com o máximo carinho e dedicação; verdadeiras mártires, elas têm a simpatia empolgante das vítimas inocentes; penso que é imperioso dever do governo cuidar dos entes espúrios, produtos da animalidade brutal e hedionda do homem sem moral. (Revista Syniatrica, 1915:118)

O professor Rocha Faria também se manifesta contra o direito ao aborto, da mesma forma que Afranio Peixoto. Este último sustenta que, sob pretexto algum, o médico pode desrespeitar a vida que já começa no momento da fecundação. E acrescenta:

É santo o ódio da mulher forçada ao bruto que a violou. Concluir daí que este ódio se estenda à criatura que sobreveio a essa violência é dar largas ao amor próprio ciumento do homem, completamente alheio à psicologia feminina. Um filho é sempre um coração de mãe que passa para um novo corpo. Só os selvagens pensam que a influência masculina é total ou dominante na criação, comparada à da mulher com a terra, na germinação das sementes.

A fisiologia e o amor depõem que todos os viventes devem muito mais às mães, do que aos pais. Porque, pois, não distinguir que esses filhos de teutões são ainda filhos de mães latinas?

A história natural conta da fecundação de certos insetos, que a fêmea sacrifica o macho, feito nutrição necessária ao seu novo estado, e, por sua vez, nascida a prole, morre, sacrificada à ela: é um símbolo. Todos os dias vemos nas sociedades humanas mulheres, separadas ou divorciadas, de amantes ou de maridos, aos quais vieram a malquerer, matálos ou se matarem na defesa dos próprios filhos que houveram deles... É que o filho é o pai idealizado; o bruto, o sedutor ou o companheiro, já não tem crime, não engana mais e é mais amado. As francesas e as belgas hão de regenerar na descendência e na criação os bárbaros que as 
ofenderam; assim os filhos vingarão os pais. (Revista Syniatrica, 1915:118-119)

Essa passagem condensa uma série de idéias em voga nas primeiras décadas do século XX. Em primeiro lugar, há a pressuposição de que o amor materno, característico da psicologia feminina, é certamente superior e capaz de superar o ultraje e a violência do estupro. O desejo do aborto seria muito mais fruto do ciúme masculino do que da vontade feminina. Afranio Peixoto não é tão explícito nesse texto, mas se recorremos à bibliografia francesa da época (sobre a qual o autor devia se apoiar), é possível perceber que está em jogo também a transmissão de caracteres hereditários indesejáveis dos alemães através das mulheres belgas e francesas. A imagem utilizada é sempre a da criação de um futuro inimigo dentro da própria casa, um medo muito grave em se tratando do contexto de disputas entre franceses e alemães, no qual se destaca a comparação entre a baixa taxa de crescimento populacional dos primeiros perante os segundos. Nesse sentido, a discussão sobre o aborto na situação da guerra colocava em cena não apenas o direito das mulheres violadas, mas hereditariedade, regeneração $e$ a relação entre população e soberania nacional.

Outro depoimento contrário ao aborto é aquele do dr. Arnaldo Quintella. Ele diz ser radicalmente contra, pois a intervenção do médico nesses casos nada mais seria do que um assassinato intra-uterino ou um infanticídio. Pondera que (chamando o aborto de infanticídio): "Mesmo que o infanticídio fosse permitido legalmente, como, na prática, ter-se a prova real da violência, isto é, do ultraje? Não há dúvida que surgiriam abusos inconfessáveis e acabaríamos por ver a medicina acoroçoando e acobertando o 'aborto criminoso'" (Revista Syniatrica, 1915:145). O grande medo apresentado por Quintella é ver a medicina sendo usada pelas mulheres para esconder as suas faltas, imaginar médicos distintos realizando os chamados abortos criminosos, mesmo sem o saber. A desconfiança mais geral em relação à honestidade das mulheres impede que se considere mesmo a especificidade da situação provocada pela guerra.

Em contraposição, temos a resposta formulada pelo professor Miguel Couto, que admite a soberania da decisão da mulher diante da opinião dos médicos: "Recebi a sua consulta-circular [refere-se a Leonídio Ribeiro], mas creio que houve equívoco no endereço, porque só uma mulher sabe o que deve fazer ao homem que a violenta e ao produto dessa violência. $\mathrm{E}$ tudo o que fizer está bem feito" (Revista Syniatrica, 1915:118). 
O especialista em medicina legal Souza Lima sustenta que as legislações são em geral intransigentes e não consideram com a devida atenção casos tão excepcionais como o aborto das mulheres violadas na guerra. $O$ autor se pergunta:

É justo, é humano que as mulheres que não podem ser amparadas pela justiça contra os autores da sua desonra, sejam por ela colhidas e castigadas, porque não se podendo conformar com aquela situação, procurem desembaraçar-se do filho gerado a contra gosto no seu ventre pela concupiscência de soldados em guerra?

Não, de certo: - summum jus, summa injuria. E nem acredito que os que pensam e se têm pronunciado em sentido contrário, se conformariam estoicamente com o respeito e obediência à dureza da lei, se o fato se passasse com pessoas de sua familia, suas esposas, filhas e irmãs.

Seria uma iniqüidade clamorosa sufragar o cumprimento da lei somente para (...) os outros, impondo às vítimas desse requinte de perversidade o sacrifício desumano ou sobre-humano de sofrerem resignadas as conseqüências dele decorrentes, ou então, para fugirem a elas $e$ à sociedade cruel que as abandona nesse angustioso transe, sugerindo-lhes a resolução heróica da protagonista d'O intruso, de Coelho Netto, recorrendo ao suicídio! Não seria para estranhar tal desenlace na situação desesperadora dessas infelizes. E se todas ou a maioria delas tomassem essa deliberação, seria burlada e perdida toda preocupação visando o direito dos nasciturnos à vida, igualmente sacrificada ao mesmo tempo que a de suas progenitoras! (Revista Syniatrica, 1915:178)

Souza Lima diz ainda que o parlamento francês negou o direito ao aborto e preferiu a criação de orfanatos para acolher as crianças recémnascidas nessa situação. Mas, na sua opinião, essa não é a melhor solução, já que ao descobrirem a "hediondez criminosa de sua origem", estes indivíduos maldirão o seu nascimento, além do que podem estar condenados pela herança de pais alcoólicos ou portadores de doenças venéreas e sifilíticas. Usando de sua autoridade em medicina legal, o autor adiciona que se a mulher que comete o crime de aborto para ocultar a desonra própria tem a sua pena diminuída (na legislação brasileira e também na de outros países), a condescendência legal também deveria ser aplicada às mulheres violadas na guerra. Os tribunais não deveriam condenar as mulheres que praticassem aborto em tal situação tão excepcional.

O dr. A. M. Teixeira Mello é quem defende o direito ao aborto de maneira mais enfática em uma resposta bastante longa. Transporta o 
problema francês para o contexto da sociedade brasileira e expressa suas posições racistas:

perguntamos se haverá brasileira, moça educada, mulher de meio superior, de cores rosadas ou morenas, que a desgraça e infortúnio houvesse feito ser violentada em uma fazenda ou roça, no meio de gritos e resistência, por um negro ascoroso, que não tivesse todos os desejos, que não fizesse todas as manobras, e que não se sujeitasse até morrer, contanto que lhe tirassem do ventre aquele fruto do coito danado! (Revista Syniatrica, 1915:119)

O autor indica como o sentido de uma gravidez pode ser variável em função de cada contexto. Depende da classe e das condições econômicas, de quantos filhos a mulher já tenha, se a gravidez é lícita ou não e da fase da gravidez em que o aborto ocorreria. Mello revela que um aborto nos primeiros meses pode ser encarado como um fato natural, já que o produto da concepção não teria grande valor. Como conseqüência, não se poderia exigir das mulheres ultrajadas que levassem a termo suas gestações, mesmo contra a vontade. O trecho seguinte ilustra este raciocínio:

Em geral, a primeira gravidez lícita, em gente superior, sobretudo, é recebida com os encantos de uma glória, que envolve os sentimentos de maternidade e paternidade, confundidos num só desejo. Após as alegrias, os prazeres se sobrepujam uns aos outros, e a mulher reúne, numa sublimidade encantadora, cinco ou seis entes que lhes são caros e que são tantas outras amarras ao amor conjugal. A mãe é então um misto de dever e alegria para com a sua prole e o seu desejo é vê-la em derredor de si, é festejar os seus filhos, fazer projetos do seu futuro, e ver neles a representação de seu amor, começado quando ainda mocinha e mantido até aquele momento, dando frutos de sua constância. Mas, se após essa meia dúzia de seres que lhe enfeitam o lar, uma nova gestação é interrompida por um acidente, por uma causa que passou até despercebida, ela em geral não se lastima muito, não vai amargurar com prantos; e, pelo contrário, encara o fato como natural e o produto como de pouca valia, tanto que o faz desprezar. A repugnância pela expulsão do produto de concepção nos dois ou três meses, dadas certas condições especialíssimas, não apresenta os horrores do fato geral.

O que era aquilo no seu começo? Nada; sangue. Sem valor. E, se este nada, este sangue procura ter vida, alento, alma, e se prepara para ser um monstro, um repelente, o que melhor? E para a filha desonrada pela violência, e que acabrunhada vê sofrer seus pais? - o que melhor?

Na França, a mulher não procura habitualmente limitar a sua prole a um ou dois filhos, e não o faz por todos os meios? Como agora, porque 
os filhos foram concebidos com violência, por homens que blasonavam a glória e fediam a fumo e a álcool, obrigá-las, condená-las a conservar esses entes intrusos? (Revista Symiatrica, 1915:120)

Teixeira Mello acrescenta que os médicos não concordam com a pobre mãe em virtude de razões acumuladas com os estudos. Mas, na prática quem sofre é ela. Portanto, "as razões médicas, as razões morais, as razões do código, não têm o direito de obrigá-la ao sacrifício, não têm o direito de abandoná-la, para não ser cúmplice, e permitir que a pobre se entregue a mãos desastradas - as fazedoras de anjos - que, desejando aliviá-la, a podem matar" (Revista Syniatrica, 1915:120). O autor lembra que abortos são cometidos em função de vícios de conformação da bacia, vômitos persistentes que muitas vezes são mal definidos ou podem mesmo ser fingidos. Como então não socorrer a mulher no caso extremo do estupro? O médico que não ajudar a mulher em tal situação pode se considerar responsável por um homicídio, se ela recorrer a uma curiosa e morrer em decorrência do precário atendimento ou se tentar o suicídio. Ninguém pode argumentar em contrário da prática do aborto pelo médico, advogando a vida do embrião, já que se sabe que nos primeiros meses trata-se apenas de um escarro sanguíneo. Na ordem social, os filhos são vistos como destinados à pátria e na situação da guerra ninguém deseja os filhos do inimigo. Na ordem natural, os filhos são para os pais e, portanto, ninguém pode culpar uma mulher que recorra ao aborto.

Para Teixeira Mello, ninguém pode culpar também o médico que auxilia a mulher em um caso como o da guerra. Em primeiro lugar, a criminalidade pressupõe a clandestinidade, o que não acontece nesta situação em que a mulher é ultrajada publicamente e recorre ao médico, um profissional, sem se esconder. O médico tem a intenção de ajudar a mulher e evitar um mal maior que seria o infanticídio realizado como último recurso pela mãe desesperada. O Código Penal de 1890 prevê, no artigo 24, que as ações que não foram cometidas com intenção criminosa não são passíveis de punição e, no artigo 32, que não são criminosos os que praticarem o crime para evitar um mal maior. Além disso, o Código Penal de 1830 - que vigorou no Brasil até 1890 - penalizava somente aquele que auxiliava ou praticava o aborto. A mulher grávida não era considerada criminosa, por dispor do fruto que concebia (Revista Syniatrica, 1915). ${ }^{1}$

As mulheres estupradas na guerra não podem ser punidas pelo crime do aborto, pois se está diante de uma conjuntura em que o próprio Estado 
perdeu o direito de punir. Não se pode castigar uma coletividade de mulheres que sofreram a sanha dos conquistadores se eles mesmos não são punidos. O autor conclui:

Nestes casos não houve o clandestino, nem o lucro; houve a legítima defesa da pessoa e honra: o desforço; não serve a correção de exemplo, nem tem utilidade e houve o desejo de evitar o mal maior; não houve a intenção criminosa, como e sobretudo, o fato foi cometido fora do Estado, sem garantias, dando maior direito à legítima defesa, e ao auxílio que ela implora. (Revista Syniatrica, 1915:154)

Respostas ao debate do aborto na guerra também apareceram em outras publicações. No Brazil Medico temos um artigo interessante. O articulista anônimo menciona que a questão sobre a legitimidade do aborto nas mulheres violadas na guerra deveria ser dirigida às mulheres, em primeiro lugar, e também aos juristas, para se obter um panorama do que pensa a sociedade brasileira. Para além dessas opiniões, a discussão é inútil e pode mesmo ser perniciosa, contribuindo para que moças violadas pratiquem o aborto supondo, erroneamente, que não poderão amar o produto do crime. A discussão é inútil, em termos médicos ou científicos, porque o que está em jogo é o amor materno, que é instintivo e inevitável. Mesmo no caso de estupro, se a mulher não desenvolve este sentimento só pode ser uma doente. Transcrevo abaixo um trecho que exemplifica essa posição:

A base da discussão, parece-nos, é inteiramente falsa. Um dos principais elementos a ponderar é a relação de simpatia entre essas mães e os futuros filhos. Ora, nenhuma dúvida pode haver nesse ponto, porquanto o amor materno não é lei de moral criada pelos nossos costumes e pela inteligência humana, é instintivo, é geral para todos os seres, tem caráter inevitável. A mulher, violentada, embora se lembre sempre com horror do momento que a fez mãe, mesmo que não queira amar o filho, quando nascido, se apegará a ele inevitavelmente e, muitas vezes, tanto mais quanto maior sacrifício represente. Quando isso não suceder, sejam quais forem as doutrinas dominantes, podemos afirmar com segurança que se trata de uma anomalia rara, de um vício orgânico, de um caso teratológico. (Brazil Medico, 1915:271)

Esse artigo ilustra a concepção que pressupõe o caráter natural e intrínseco da ligação afetiva da mãe com o filho e reduz qualquer desvio à patologia. Como conseqüência, a recusa em ter filhos, e mesmo os atos de aborto e infanticídio só podem ser entendidos como manifestações doentias 
resultantes de perturbações de ordem física ou mental. A prática do aborto e infanticídio nessa perspectiva jamais é pensada como uma atitude consciente, embora possivelmente desesperada, de cada mulher.

No mesmo ano temos também a publicação de um pequeno livro de autoria de Erico Coelho, personagem sempre presente nas polêmicas médicas da época. Nesse trabalho, o autor mostra irritação com os médicos franceses empenhados em coibir a queda da natalidade e que apelam com esse argumento para proibir o aborto das mulheres estupradas na guerra. Afirma que desde 1909 vem questionando esta 'puericultura intra-uterina' francesa que faz da obstetrícia uma arma de defesa nacional. Acredita que no ano de 1915 esteja ainda pior esta 'obsessão' com uma 'economia do homem coletivo'. E acrescenta que a preocupação com a mãe-pátria e com o povoamento do país tem sustentado a 'hipocrisia' dos médicos que negam o aborto às estupradas. Finaliza dizendo que, como médico cristão, não hesitaria em socorrer a vítima do estupro, ansiosa por abortar (Coelho, 1915:39-40).

As afirmações de Erico Coelho quanto ao aborto no caso das violentadas na guerra mereceram destaque na compilação publicada por Leonídio Ribeiro em 1930. Tinha sido Ribeiro o instigador da polêmica no Brasil. E esta publicação tardia, de 1930, nada mais é do que a conclusão do médico a respeito das discussões anteriores. ${ }^{2} \mathrm{O}$ autor começa o texto manifestando a sua revolta contra as declarações feitas por Erico Coelho em uma aula, ainda no ano de 1915, em que se colocava a favor do aborto no caso discutido. Comenta também as repostas dadas por Souza Lima e Teixeira Mello (já citadas) igualmente favoráveis. E recorre ao 'mestre da medicina legal' Afranio Peixoto para reforçar seu argumento de defesa da vida do feto. Ribeiro parece querer encerrar a questão de uma vez por todas, confirmando a criminalidade do aborto e desqualificando as opiniões de Coelho, Souza Lima e Teixeira Mello. ${ }^{3}$

A questão do aborto para mulheres estupradas na guerra mobilizou médicos famosos e permitiu que se expusessem perspectivas sobre a legitimidade deste ato, a natureza do amor materno e o comportamento a ser seguido pelos médicos. Mas discutiu-se sobretudo a partir do caso francês. Este fato não é sem importância. Revela a atenção de nossos especialistas com as polêmicas candentes na Europa e deixa claro como a questão da baixa taxa de natalidade francesa era considerada um assunto relevante. Na verdade, o tema da natalidade já há algum tempo vinha se consolidando como um problema de grande importância. 


\section{A Luta nas Instituições Médicas}

Uma revista feita nas páginas dos periódicos especializados mais importantes das primeiras décadas do século XX revela que as discussões em torno do aborto e do controle da natalidade mobilizaram os médicos com grande freqüência. Entre 1915 (o ano da discussão sobre o aborto das vítimas da guerra) e o começo da década de 1920, o debate em torno desses assuntos foi constante, havendo grande destaque para a prática do chamado 'aborto criminoso' no Rio de Janeiro.

Em outubro de 1915 o Brazil Medico transcreve a ata de uma sessão da Academia Nacional de Medicina na qual Alfredo Nascimento propõe a seguinte moção:

A Academia Nacional de Medicina, de muito vexada pelos abusos sem conta que quotidianamente se praticam em torno do exercício da profissão médica, sempre respeitável e dignificada por quantos a têm exercido como um verdadeiro sacerdócio, que a tradição vem mantendo à altura do seu elevado expoente moral, sobrelevando-a acima do nível montante da exploração desonesta e criminosa que a macula, patenteia o seu júbilo e firma o seu apoio moral, ante a atitude assumida pelas autoridades policiais, mostrando o seu empenho em fazer cair sob a ação das leis penais os delinqüentes que impunes por aí pululam em multidão crescente, abusando da credulidade popular, e bem assim endossa as judiciosas ponderações aduzidas a respeito em editorial do ' $O$ País' de hoje, chamando a atenção, nesse particular, sobre os repetidos crimes de aborto tão largamente praticados, como é pública e notoriamente sabido, aliás pelos próprios anúncios quotidianos em todos os jornais, onde a prática desse delito é cada vez mais claramente oferecida. (Brazil Medico, 1915:358)

Destaca-se nesta moção a idéia de uma elevação moral da Academia Nacional de Medicina, e dos médicos em geral, em contraste com os charlatães praticantes de aborto que devem ser perseguidos pela polícia. Na mesma reunião, Eduardo Meirelles e Olympio da Fonseca fazem referências sobre o assunto e acentuam a gravidade do aborto criminoso. A moção é aprovada unanimemente (Brazil Medico, 1915:358).

Em maio de 1918, a Academia Nacional de Medicina retoma a discussão, a partir do discurso proferido por Nascimento e Silva. Este orador insiste na necessidade de combater o aborto criminoso advogando uma ação rigorosa da lei. Recorda a campanha feita no mesmo sentido pelas sociedades científicas da França. Naquele país, o problema tomava proporções 
alarmantes. Somente em Paris, entre 25 e 30 mil abortos eram praticados criminosamente a cada ano. O pavor de que o Brasil também chegasse a tal estado motiva Nascimento e Silva a solicitar que a Academia se posicionasse e reclamasse providências aos poderes públicos. Os anúncios publicados nos jornais pelos praticantes do aborto são mais uma vez o material utilizado para provocar a reação dos ouvintes (Brazil Medico, 1918:158).

O orador ainda descreve a proposta elaborada pela Sociedade de Medicina Legal da França. Nesta proposta, que seria encaminhada ao parlamento francês, previa-se a vigilância das casas de assistência à mulher, a proibição de publicações favorecendo a provocação do aborto e a notificação compulsória dos casos, além da absolvição da abortada ou a redução da pena desde que ela revelasse o nome do abortador. Nascimento e Silva termina propondo a nomeação da uma comissão para fazer um estudo da questão e redigir um projeto que seria encaminhado pela Academia Nacional de Medicina ao Congresso Nacional. Para essa comissão foram designados o próprio Nascimento e Silva, Afranio Peixoto, Carlos Seidl, Fernando Magalhães e Olympio da Fonseca.

Em setembro de 1918, o estudo da comissão já havia sido elaborado e sofria críticas dos outros membros da Academia. Em sessão de 26 de setembro, Nascimento e Silva defende o projeto da comissão e o debate continua. Arnaldo Quintella propõe alterações, embasado nos seus quinze anos de prática. Revela que a taxa de abortos provocados no Rio de Janeiro era muito alta; condena os obstetras que se dedicam a esta prática pelo ganho financeiro e diz que há muito tempo vem denunciando este comércio repugnante assentado sobre o crime de 'infanticídio' (Brazil Medico, 1918:389-390). Mais uma vez, aborto e infanticídio pareciam ser a mesma coisa.

A discussão, pelo que consta da documentação, só foi retomada em 1920. Em maio desse ano, Nascimento e Silva faz um pronunciamento afirmando ter se afastado das discussões sobre o aborto por esperar um momento mais propício para retomá-las. Propõe que este problema 'biossocial' retorne à ordem do dia da Academia Nacional de Medicina. Nas sessões seguintes, Fernando Magalhães, então diretor da Pró-Matre, evoca elementos que permitem compreender porque a discussão foi interrompida em 1918. O parecer, elaborado pela comissão e redigido por Nascimento e Silva, sofreu sérios ataques, que, segundo Magalhães, visavam mais aos signatários do que às suas disposições. A situação parecia ter chegado a um impasse de tal proporção que o debate fora abandonado. 
Entre os principais críticos da proposta, estavam Belmiro Valverde e Julio Novaes. O primeiro disse que o projeto elaborado pela comissão era apenas uma cópia da proposta francesa sem qualquer adaptação à situação brasileira. A isso Magalhães responde que "o aborto é igualmente prejudicial debaixo do clima tropical ou do clima frio da França" (Brazil Medico, 1920:317). Julio Novaes, além de defender abertamente as idéias malthusianas, posiciona-se contra a diminuição da pena da abortada que denunciasse o abortador. Magalhães mantém a proposta desse tipo de indulto. Já o dr. Olympio da Fonseca declara que é a favor do parecer da comissão, mas discorda da notificação compulsória pelo médico dos casos de aborto. Acrescenta que a abortada, sabendo que o médico irá denunciála, retardará o chamado. Magalhães retruca que, por instinto de sobrevivência, ela não procederá desta maneira (Brazil Medico, 1920:334).

A diminuição da pena para a denunciante e a notificação compulsória dos casos eram temas que centralizavam os debates em várias sessões. O princípio do segredo médico é evocado por aqueles que eram contra ou a favor dessas propostas. Em sessão do mês de julho de 1920, o dr. Miguel Couto declara que a notificação compulsória de todos os casos de aborto incorreria em uma injustiça contra as mulheres. Afirma que o médico não tem o direito de revelar os segredos que ouve à cabeceira da paciente, mesmo que tenha que sofrer a pena de prisão. Diz que esse tipo de notificação não se assemelha à divulgação das doenças contagiosas, pois nesse último caso está em jogo a proteção de outras pessoas. Fernando Magalhães retruca, afirmando que a notificação do aborto tem por fim a proteção da sociedade e que o aborto é uma "doença social eminentemente contagiosa". Miguel Couto lembra que na sua estatística pessoal, o aborto natural representa $80 \%$ dos casos, muitas vezes sendo resultado do comportamento de homens que entram para a família com sífilis e blenorragia, transmitindo-as às suas mulheres. Notificar estes casos seria trazer ainda mais sofrimento a estas mulheres, o que seria agravado com o exame por um médico estranho chamado para investigar a causa do aborto e determinar se foi criminoso ou não. Couto ainda pergunta aos colegas se consentiriam que alguma pessoa de sua família fosse examinada por um médico desconhecido. A discussão torna-se mais uma vez 'acalorada' (termo sempre usado pelo redator das atas) e encerra-se a reunião (Brazil Medico, 1920:486). ${ }^{4}$

O tema da notificação do aborto colocava em disputa aqueles que eram partidários da submissão do médico a normas gerais de conduta e da 
intervenção nos casos de aborto, por meio da autoridade médica, da polícia, do Estado, e aqueles que privilegiavam o livre arbítrio de cada profissional. Também estava em jogo se a relação médico-paciente era de natureza pública ou privada. Enquanto Magalhães defende a elaboração de regras definidas que desconsideram qualquer particularidade inerente às situações, Miguel Couto recorre ao direito de cada médico de agir em cada caso de acordo com a sua consciência.

Na sessão de 27 de maio de 1920, o dr. Dias de Barros aprofunda a discussão em alguns pontos, especialmente em torno do neomalthusianismo. Declara que, ao contrário do que fora mencionado em reuniões anteriores, o embrionicídio não é um homicídio. A própria Igreja reconheceria este fato, pois pretende que o indivíduo até o batismo é apenas um homem em potencial. Posteriormente, justifica o neomalthusianismo dizendo que o Estado não pode impedir que o indivíduo limite a sua prole em conformidade com as suas posses. Tentando justificar sua posição, recorre à polêmica gerada com o processo de esterilização desenvolvido pelo médico Abel Parente e elogia 'calorosamente' a sua defesa, feita pelo professor Francisco de Castro. Termina afirmando que o neomalthusianismo é prova de adiantamento de um povo e diz que o povo francês deu esse exemplo, lutando contra as tentativas intervencionistas do Estado (Brazil Medico, 1920:361). Em 10 de junho, Fernando Magalhães responde ao colega, alegando que a Igreja considera o embrião pessoa de direito desde a concepção. Além disso, afirma estranhar o elogio das práticas neomalthusianas ou a dúvida sobre a criminalidade do aborto provocado. Acrescenta que a lei de Malthus é um erro patente, e que se Malthus, ríspido pastor protestante, soubesse que seu nome servia de designação a práticas tão infames, certamente sentiria profundo desgosto.

Também se coloca em discussão a dúvida a respeito de se, na França, a mesma comissão trata das questões do aborto e do despovoamento ou se havia duas comissões diferentes. Esse tema parecia ser crucial para os médicos, pois determina a extensão que a questão do aborto poderia assumir. O dilema era se se tratava apenas de um problema específico ou da sua relação com o contexto mais geral de cada sociedade referente ao crescimento populacional. Outro ponto levantado relaciona-se ao atendimento prestado à mulher e à criança. $O$ dr. Arnaldo Quintella sugere que se incluam no parecer medidas de proteção à maternidade e à infância, que garantissem a subsistência e o atendimento médico às mulheres 
sem condições financeiras que levassem a termo gestações indesejadas e desamparadas.

As intervenções resumidas anteriormente mostram como a discussão sobre um projeto de repressão ao aborto criminoso não se restringia ao tema de forma específica. O papel do médico era certamente um dos quesitos que mais preocupava os membros da Academia Nacional de Medicina. Assumir uma posição unânime em relação à denúncia dos casos de aborto ou exigir da mulher o nome do praticante, que em muitos casos era um médico, seria uma conquista ainda distante.

Outro item importante é a introdução do tema da proteção às futuras mães e às crianças como meio de diminuir os casos de aborto. $O$ discurso do dr. Dias de Barros expressa como contracepção e aborto eram considerados temas muito próximos. ${ }^{5}$ A recorrência do malthusianismo ou neomalthusianismo nos debates mostra como o aborto era visto dentro do conjunto das práticas de restrição da natalidade. E quanto a esse delicado tema, os médicos deveriam se posicionar dentro de um contínuo, no qual as posturas extremas eram, de um lado a condenação de todas as iniciativas nesse sentido, desde a utilização de condons até o aborto, e de outro a aprovação de todos os métodos. É interessante que, apesar de se poder supor diferentes posições, por exemplo, em relação a cada método, o que fica mais patente nos debates públicos é a contraposição entre os defensores da moral, que repudiavam o controle da natalidade, e os chamados neomalthusianos, adeptos da contracepção.

Talvez esta polarização faça mais sentido se consideramos que há questões políticas mais abrangentes sustentando estas posições. Inspirados pelo debate que ocorria na França, os médicos brasileiros que condenavam a restrição da natalidade tinham em mente não apenas argumentos morais, mas também o medo da 'depopulação' que, em última instância, ameaçaria a soberania nacional. É certo que aqui não tínhamos tantas guerras como na Europa, mas tínhamos um extenso território ainda despovoado, com fronteiras abertas aos invasores, além de um 'problema' interno relativo à mistura racial. Nesse sentido, a natalidade era um problema de Estado e, portanto, cabia a este intervir para garantir a segurança dos seus cidadãos. A repressão ao aborto e também a todas as outras práticas de controle da natalidade era considerada legítima.

Do ponto de vista dos neomalthusianos, a vida sexual e reprodutiva era uma questão individual. Cabia a cada um decidir sobre o número de filhos, colocando em prática os meios que achasse mais adequados. Além 
disso, alguns partidários dessa doutrina também advogavam que os suplícios da humanidade eram devidos ao excesso de população. $O$ controle da taxa de natalidade era visto como positivo pelos neomalthusianos.

O dr. Julio Novaes defende o neomalthusianismo por meio de uma referência a Clemenceau, eminente político francês que teria chamado os operários que tinham muitos filhos de 'pobres imbecis'. Na França, segundo Richet, o casal tinha o número de filhos que queria e podia. Novaes acrescenta, mais uma vez tratando do aborto dentro do que denomina neomalthusianismo, que vários autores importantes opinam pela não punição do aborto provocado. Mas, é discutindo a questão da 'depopulação' que temos a sua contribuição mais interessante. $\mathrm{O}$ autor começa falando que a 'depopulação' é um problema que não existe de forma significativa no Brasil. Ao mesmo tempo, diz que se existe, não se deve à prática do aborto, como afirmam os seus opositores, mas ao feminismo. O feminismo estaria desviando a mulher dos seus misteres, provocando o seu desinteresse pela família e, dessa forma, diminuindo a taxa de natalidade. Novaes faz uma conexão explícita entre a emancipação feminina e a recusa às gestações sucessivas. É importante chamar a atenção ainda para o fato de que este autor, por um lado, defende o controle da natalidade e, por outro, vê com maus olhos a emancipação feminina e o afastamento da mulher da maternidade. Este é um exemplo das muitas combinações possíveis feitas pelos médicos envolvendo a questão da sexualidade e reprodução.

Os debates sobre o aborto não ficaram restritos somente à Academia Nacional de Medicina. Outras entidades importantes, como a Sociedade de Medicina e Cirurgia do Rio de Janeiro, também discutiram a questão. Nessa organização, a questão da notificação compulsória dos casos de aborto e sua relação com o segredo profissional também foi um tema central. Na sessão de 21 de setembro de 1920, por exemplo, o dr. Barros Barreto, depois de passar em revista às legislações de vários países sobre o assunto, propõe uma solução, segundo ele, de conciliação das posições divergentes. O médico só notificaria os casos suspeitos ou comprovados de aborto criminoso e faria este comunicado ao gabinete médico-legal, que, após a perícia necessária, encaminharia às autoridades o laudo afirmativo para andamento do processo criminal. Nessa hipótese, o andamento dos casos fica ainda mais sob o poder dos médicos. Na Sociedade, também havia posições contrárias à notificação, como a do dr. Carlos Fernandes, que advoga ser inútil a notificação, tendo em vista que o diagnóstico diferencial entre aborto provocado e espontâneo é dificílimo. Sugere que as autoridades e o 
Estado devem preocupar-se antes com a proteção das crianças e dos pais do que com a punição dos abortadores. Também nessa instituição foi constituída uma comissão para o estudo do problema do aborto criminoso (Brazil Medico, 1920). ${ }^{6}$

\section{O Debate no Primeiro Congresso Nacional dos Práticos}

No ano de 1922, quando se reunia o Primeiro Congresso Nacional dos Práticos, o tema do aborto criminoso volta a ter destaque. Nesse Congresso, foi debatida uma série de assuntos que mostram a preocupação da medicina da época com questões sociais. O papel do médico no combate à pobreza e o analfabetismo foram alguns dos tópicos levantados. Mereceram destaque também o charlatanismo, a liberdade profissional e a legislação sanitária do país. A preocupação com a higiene, as doenças venéreas, a degeneração e o aborto provocado eram os temas que disputavam as atenções.

Na quinta sessão ordinária, por exemplo, que contou com a presença de 106 congressistas, houve a apresentação dos seguintes trabalhos: "Luta contra as doenças venéreas", do dr. Eduardo Rabello, "A luta contra as degenerações nervosas e mentais", dos drs. Juliano Moreira e Antonio Austragesilo e "A cumplicidade do profissional nos crimes de aborto", da dra. Ermelinda de Vasconcellos. O trabalho de Rabello discute a propaganda antivenérea, o papel do Estado, as leis de saneamento do casamento e a educação higiênica. Juliano Moreira trata da amplitude que deve encampar o conceito de degeneração, abrangendo até a noção de inadaptabilidade social dos indivíduos, o que permitiria que um maior número de casos fosse atingido pelas medidas profiláticas que visam a salvaguardar a higiene mental dos povos. Propõe o combate às infecções, infestações e intoxicações, que constituem os maiores fatores 'diseugenéticos' da humanidade. Uma campanha nesse sentido deveria reduzir as doenças venéreas - o que diminuiria em 30\% o número de doentes nervosos e mentais -, os abusos das bebidas alcoólicas e outros inebriantes - suprimindo em mais $40 \%$ os casos de distúrbios mentais - e evitar a procriação entre 'gentes taradas' (uma redução de mais 20\%). A guerra à uncinariose e outras verminoses completaria o combate.

Moreira acrescenta: "Enquanto não obtivermos da aplicação dos preceitos da eugenética utilizáveis entre os homens, a redução máxima nas cifras de atipias nervosas e mentais, alargaremos por mais exeqüível que o é, o raio de ação da higiene mental" (Brazil Medico, 1922:225). Para tanto, 
era preciso ensinar a criança a combater os "fatores diseugenésicos da espécie" e, aos adultos, que a higiene mental é o melhor meio de profilaxia contra os fatores de "degradação da nossa gente". Austragesilo adiciona que a luta contra as degenerações neuropsíquicas deveria divulgar os perigos da hereditariedade mórbida, educar psicossexualmente a criança (nesse item apóia-se em Freud), combater as infecções, as intoxicações e a miséria, orientar as seitas religiosas, evitar os cataclismos sociais, agir sempre a partir dos princípios da ciência e construir, nas bases da 'Eugênica', as fórmulas de melhoria da espécie humana (Brazil Medico, 1922:225-226).

Citei as propostas anteriores, porque fornecem elementos para se ter uma idéia de em que contexto se davam as discussões sobre aborto e contracepção. $\mathrm{O}$ combate às doenças venéreas, inclusive por medidas restritivas ao casamento dos infectados, a higiene mental e outras propostas indicam o peso que a eugenia ocupava no pensamento de nossos mais ilustres doutores. A noção de melhoria da espécie implicava uma postura intervencionista da medicina que também era defendida por muitos no caso do aborto criminoso. O trabalho da dra. Ermelinda de Vasconcellos conclama as autoridades a intervirem energicamente na punição da gestante e de seu cúmplice no crime do aborto (Brazil Medico, 1922:226).

A proposta sugerida pelo dr. Oliveira Motta, apoiada por Afranio Peixoto, é ainda mais incisiva. Constitui uma das várias moções apresentadas no Congresso. Transcrevo-a integralmente:

O I Congresso Nacional dos Práticos, reconhecendo a freqüência devastadora do aborto criminoso na cidade do Rio de Janeiro, julga necessária a adoção de uma luta contra esse flagelo social, e recomenda as seguintes medidas:

1. Propaganda intensiva contra as idéias de restrição à natalidade, feita pelo Departamento Nacional de Puericultura, em conferências e publicações largamente disseminadas pelo povo.

2. Proibição e repressão de toda e qualquer propaganda neomalthusiana.

3. Proibição e repressão de anúncios e quaisquer publicações e atos favorecendo a prática do aborto.

4. Vigilância ativa e efetiva dos casos de partos.

5. Notificação, à Autoridade Sanitária, dos casos de mortinatalidade e de aborto, como já se realiza, compulsoriamente, com várias doenças infecto-contagiosas. 
6. Punição severa da revelação do segredo médico, devido e garantido, em absoluto, exceto nos casos de aborto criminoso, às gestantes recolhidas às casas de partos, às maternidades privadas ou às assistências públicas, regularmente instaladas.

7. Evitar a impunidade do crime de aborto, entregando-o ao julgamento do juiz togado.

8. Absolvição da penalidade à abortada que revelar o nome do abortador.

9. Ao médico clínico, dispensado por lei de, perante a justiça, dar o seu depoimento, desde que assim o exija a sua consciência, facultar a liberdade de poder depor, em justiça repressiva, sobretudo contra os abortadores.

10. Direito de citação direta, no crime de aborto, às associações médicas, às administrações de assistência pública, a todos os estabelecimentos públicos, tendo por fim o reerguimento da população ou da moralidade. (Brazil Medico, 1922:222)

Essa proposta se aproxima muito do que havia sido sugerido pela comissão formada na Academia Nacional de Medicina, inspirada no projeto francês. De certa forma, sua divulgação no congresso representa uma vitória contra os partidários do neomalthusianismo. Na extensa lista de moções apresentadas, nenhuma se refere à defesa da contracepção ou do direito ao aborto. Mas, além daquela redigida por Motta, há várias que advogam a notificação compulsória, a censura aos anúncios, a punição do aborto (Brazil Medico, 1922:233-236).

A censura aos anúncios que incentivavam a prática do aborto ou o neomalthusianismo aparece com destaque no projeto de Motta. A publicidade parece ser percebida como a estratégia central, utilizada pelos partidários do controle da natalidade, mas que agora seria conquistada pelos médicos respeitáveis. O primeiro item da moção refere-se diretamente à propaganda contra as idéias de restrição da natalidade. ${ }^{7}$ Ou seja, o autor parece convencido de que era preciso conscientizar a população de que não deveria restringir o número de filhos. É uma pena que Motta não tenha desenvolvido a argumentação sobre porque a restrição da natalidade seria tão perniciosa. Contudo, o fato de ter apelado para o Departamento Nacional de Puericultura como responsável pela propaganda positiva indica que estava em jogo a proteção das crianças em consonância com a valorização de altas taxas de natalidade, objetivo central daquele órgão do 
governo. Ainda é preciso lembrar que a moção não trata da questão do aborto a partir do enfoque moral, mas relaciona, de várias formas aborto e contracepção, reforçando a idéia de que o núcleo central do argumento é o receio da restrição da natalidade.

\section{Contracepção e Eugenia}

O médico, especialmente aquele que trabalha em áreas ligadas à reprodução, como é o caso do ginecologista e do obstetra, passa a contribuir de maneira singular no processo que transforma o sexo e a reprodução em um assunto de Estado. Nas primeiras décadas do século $\mathrm{XX}$, o forte tom nacionalista que imperava em muitos países, inclusive no Brasil, tinha como uma de suas implicações uma preocupação mais acentuada com a população. O crescimento do número de cidadãos adquiria uma importância estratégica, tanto no que se refere à garantia da soberania, por meio do poder militar, quanto na implantação da atividade industrial e do mercado em larga escala. A quantidade, e também a 'qualidade' do povo que compunha uma nação provocavam cada vez maior interesse. ${ }^{8}$

Esse fato pode ser exemplificado com o artigo publicado no Brazil Medico em 1912 a respeito do Congresso de Eugenia realizado em Londres no mesmo ano. Nesse texto, a eugenia é definida como "a ciência que estuda os meios de aperfeiçoar a raça humana, pelo melhoramento do vigor e da saúde da prole" (p. 358). É apresentada como uma aspiração antiga que no momento passava a ter a vantagem de envolver processos científicos por meio dos quais se estudavam as causas da decadência da raça e os remédios adequados para impedi-la.

Uma questão fundamental para os eugenistas era "o impedimento da procriação por parte dos sujeitos que, por doença ou defeito transmissíveis por herança, só podem dar ao mundo filhos também doentes e defeituosos" (Brazil Medico, 1912:358). Nesse contexto, a iniciativa de vários estados dos Estados Unidos que formulavam leis de esterilização dos degenerados era vista com admiração.

Comenta-se ainda que o 'animal humano' tem sofrido o mais cruel abandono, enquanto para os outros animais se tomam providências para a obtenção de produtos vigorosos e de raça pura. No caso do homem, dá-se liberdade aos degenerados para que propaguem a sua espécie doentia, criminosa e malfazeja. Perpetuam-se hereditariamente a imbecilidade, a loucura moral, a paranóia, a epilepsia, o cretinismo e a delinqüência profissional. 
O artigo termina propondo que também sociólogos e legisladores atentem para a necessidade da esterilizacão dos degenerados e deficientes porque "já é tempo que para na procriação do animal humano se tome um pouco daquele cuidado que tão prodigamente se dispensa aos outros animais chamados de 'raça', como se o homem não devesse ser o de raça mais fina e pura" (Brazil Medico, 1912:359).

Em 1916, a Revista Syniatrica também defendia a esterilização. $\mathrm{O}$ argumento central do artigo girava em torno da idéia de que não bastava a reforma das leis do matrimônio em prol da saúde dos que estavam para nascer. Era preciso colocar os indivíduos doentes e perigosos para a sociedade em absoluta impossibilidade de procriar, recorrendo à esterilização. Dessa forma, tuberculosos, doentes mentais, epilépticos, imbecis, paralíticos, alcoólicos crônicos, além de delinqüentes, não se reproduziriam mais. O sucesso dos Estados Unidos neste empreendimento mais uma vez é louvado (Revista Syniatrica, 1916:77-78).

Também nas teses da Faculdade de Medicina do Rio de Janeiro encontram-se referências à esterilização. É o caso, por exemplo, do trabalho Da esterilização de anormais como fator eugênico, defendida por Manoel Tavares Neves Filho em 1921. O autor faz referência a uma extensa bibliografia e menciona as diversas instituições internacionais e nacionais que se dedicavam aos fins eugênicos. Ele distingue as três partes da eugenia: a positiva, favorável às procriações sãs; a negativa, contrária à procriação dos anormais; e a preventiva, que cuida dos fatores disgênicos. Faz um histórico do uso da esterilização, que, no momento, passava a comportar o objetivo preciso de "impedir a perpetuação da classe inútil dos idiotas, imbecis, amorais e criminosos constitucionais, elementos negativos na formação das Sociedades Modernas e no progresso das nações que trabalham" (Neves Filho, 1921:14). Nota-se, aqui, a associação entre eugenia, modernidade, nação e trabalho, que constituiria um dos elementos fundamentais do discurso médico da época.

O autor constata que, enquanto nos Estados Unidos, muito se fazia em favor da eugenia, no Brasil, país de imigração, cruzamentos intensos, promiscuidade, havia se avançado muito pouco. O número de anormais se tornava assustador, indicando que se estaria atravessando uma verdadeira onda avassaladora de degeneração, já que os indivíduos indesejáveis se reproduziam muito mais rapidamente que os normais. Neves Filho adverte que este é um problema de saúde pública e defende que "Assim como fazemos a profilaxia da imigração, no afastamento dos 'indesejáveis', deverí- 
amos também fazer profilaxia da degeneração, no combate à proliferação dos nossos 'indesejáveis'" (Neves Filho, 1921:21). O autor admite que as medidas eugênicas têm motivado críticas, entre as quais se destaca a concepção de que a esterilização é desumana. Contrapõe-se a tal prática, reafirmando que a eugenia é um salutar meio de aperfeiçoamento e que a "indicação científica" constituiria uma garantia contra os abusos (Neves Filho, 1921:33-36). Mais uma vez, a noção pouco nítida de indicação científica, que inclui exames feitos por um antropólogo, um psiquiatra, um clínico e um cirurgião, parece resolver o problema, deixando as decisões na mão dos médicos e cientistas.

Se recorrermos às páginas dos Annaes Brasileiros de Gynecologia, veremos que a preocupação dessa especialidade médica com a eugenia era também bastante considerável. Esta revista, de periodicidade mensal, havia sido fundada por Arnaldo de Moraes em 1936. ${ }^{9}$ No editorial publicado no primeiro número, é definida como uma obra de cunho exclusivamente científico e como o órgão oficial do ensino da clínica ginecológica ${ }^{10}$ da Faculdade de Medicina do Rio de Janeiro e da Faculdade Fluminense de Medicina. O editorial diz ainda que, seguindo a concepção alemã do ensino e prática da especialidade, a revista se ocupará também da obstetrícia. E termina fazendo referência à abrangência dos temas tratados, incluindo explicitamente o campo eugênico: "Também terá acolhida em suas folhas tudo o que se relacione com qualquer problema mesmo extragenital da patologia feminina, quer no campo endócrino-metabólico, quer no campo psicológico, psiquiátrico, biológico, genético e eugênico" (Annaes Brasileiros de Gynecologia, 1936:1). ${ }^{11}$ A revista tinha também a pretensão de representar um elo de ligação entre os profissionais e estudantes brasileiros com a produção de conhecimento desenvolvida internacionalmente. Apresentava resumos dos artigos publicados nos principais periódicos da área em todo o mundo. ${ }^{12}$

A quantidade de artigos e resumos de publicações, especialmente alemãs, que se referem à eugenia e em particular à esterilização é bastante considerável. Somente no primeiro ano (volumes I e II), encontram-se dez textos que tratam do tema da esterilização. Ao mesmo tempo, destacamse também os artigos em torno do problema da esterilidade e da proteção à maternidade. Os editoriais da revista acompanhavam este movimento. ${ }^{13}$

O editorial do número três (1936, v.II, p. 228-231), por exemplo, trata da lei de esterilização na Alemanha e de sua importância social. Ao médico cabia atuar como juiz no tribunal especial, que dava a sentença da 
esterilização, e denunciar os casos de doença hereditária que eram passíveis da prática da esterilização. ${ }^{14} \mathrm{~A}$ operação seria executada por um cirurgião ou ginecologista. Há informações também a respeito do número de esterilizações realizadas na Alemanha ${ }^{15}$ e sobre os métodos, em geral, referentes à extirpação das trompas. Menciona-se ainda que, para o futuro, a intenção seria esterilizar as meninas em idade entre 10 e 14 anos. A interrupção da gravidez também seria possível em alguns casos. Já a castração poderia ser decretada pelo tribunal com o consentimento do condenado, para livrá-lo de um instinto sexual degenerado. O editorial não chega a se posicionar favoravelmente à lei de esterilização, apenas menciona que implica um "grande alcance social". Contudo, também não critica sequer um dispositivo apresentado. O tom geral parece ser mais de admiração do que de condenação.

A mesma característica pode ser observada na resenha feita do trabalho do médico alemão Engelmann, que relata que eram realizadas 810 esterilizações por semana no hospital em que trabalhava. A maioria dos casos era de moças alienadas que, algumas vezes, eram operadas contra a sua própria vontade. Muitas vezes, tratava-se de crianças, e a operação tornava-se bastante delicada. $\mathrm{O}$ autor terminava por recomendar o casamento entre esterilizados, evitando ao mesmo tempo a propagação de doenças e de delitos sexuais (Annaes Brasileiros de Gynecologia, 1936:240-241).

No mesmo ano, a revista publica um extenso artigo do dr. Francisco de Carvalho Azevedo, ${ }^{16}$ onde a esterilização era um dos temas discutidos dentro do problema mais geral da 'concepção consciente'. Esse artigo é bastante revelador das tensões entre diferentes posições em curso na época. O autor utiliza como epígrafe trechos de Fernando Magalhães, que fala da maternidade consciente, de Arnaldo de Moraes, sobre o papel do médico que deve instruir o casal sobre os meios de evitar a gravidez quando há indicação científica, e de Afranio Peixoto, que sugere que para evitar o aborto deve-se recorrer ao 'mal necessário' da anticoncepção. Azevedo diz que estas citações são verdadeiras profissões de fé, e afirma que o problema da concepção consciente envolve conflitos de natureza científica, moral e religiosa. Passa a falar então dos modernos estudos de Ogino e Knaus sobre a fisiologia da reprodução humana e do esclarecimento que trazem sobre pontos obscuros envolvendo os fenômenos da ovulação. Através deles, ficou provada a existência de uma época da fecundidade e outra da esterilidade dentro do ciclo menstrual da mulher. Isso resolveu o problema da concepção do ponto de vista científico. Da perspectiva da religião, pode-se dizer 
que a Igreja condescendeu na aplicação da continência periódica em circunstâncias especiais. E em termos morais, o método natural conquistou a aprovação mesmo daqueles que condenavam as práticas neomalthusianas e o aborto criminoso (Azevedo, 1936:255-257).

O autor explica que vinha utilizando o estudo do método de OginoKnaus há quatro anos, recomendando-o nos casos cientificamente indicados, o que totalizou mais de 50 experiências. É com base nesse trabalho, e diante da "inexistência de outra contribuição nacional documentada sobre o assunto", que apresenta as suas conclusões. Azevedo explica que o método de Ogino-Knaus pode ser aplicado não só na regularização ou controle da natalidade, mas também no sentido positivo, favorecendo a concepção. Também facilita a determinação da duração da gravidez e a data provável do parto, o que pode contribuir para a pesquisa médico-legal da paternidade. Contudo, o autor se mostra bastante preocupado em fazer a distinção entre esse método e outros meios empregados no controle da natalidade:

Enquanto o método natural de regularização da concepção pela continência periódica salvaguarda a função procriadora tal não sucede com o arsenal neomalthusiano, cujas práticas artificiais e malsãs aniquilam a capacidade geradora $e$ favorecem a esterilidade definitiva.

Entre o método de Ogino-Knaus e o chamado Neomalthusianismo há um insondável abismo. (Azevedo, 1936:475)

Segundo Azevedo, o ginecologista de Flensburgo, Messinga, em 1882, aproveitando-se da confusão causada pelas idéias de Malthus, propôs resolver o problema da restrição da natalidade mediante o emprego de um pessário vaginal oclusivo. Com ele teria nascido o neomalthusianismo. Em 1883, combatendo o neomalthusianismo, Capellmann apresenta a continência periódica como a verdadeira solução que conciliaria a ciência e a moral. Seu método não teve grande sucesso e as práticas artificiais tomaram maior impulso. Para o autor, apesar da oposição dos moralistas, da repulsa dos teólogos e da advertência dos médicos, não estava mais sendo possível conter a avalanche da propaganda anticoncepcional, elaborada pelos leigos: "Não encontrando eco no meio científico, encarregam-se os leigos da difusão das doutrinas subversivas, inventando novos meios, criando jornais, fundando postos de consulta anticoncepcionais" (Azevedo, 1936:476). Diante dessa situação, os médicos tomaram uma nova posição: 
Em face do mal inevitável da anticoncepção resolveu a classe médica encarar o lado científico do problema. Pela imprensa, pela tribuna, pela cátedra, vozes autorizadas manifestam suas opiniões. Publicam-se livros, reúnem-se congressos. E os laboratórios trabalham ativamente procurando analisar e descobrir na química moderna o melhor meio espermicida.

E após tanto trabalho perdido ressalta a opinião unânime de que o meio anticoncepcional ideal está por descobrir e que todos os métodos retirados da física (raios X e radium), da mecânica (condom, pessários, esteriletes), da química (lavagens, velas e supositórios antissépticos) e da biologia (hormônios) ou falham fragorosamente ou arruinam gravemente a saúde.

O método de Ogino-Knaus, provado pela ciência, aconselhado pela moral, tolerado pela religião, é inatacável e é o único que resolve maravilhosamente todas as faces do angustioso problema da concepção consciente. (Azevedo, 1936:476)

É possível perceber como Azevedo é cuidadoso em explicar porque, historicamente, a medicina chegou a se dignar a tratar da questão da anticoncepção. Certamente não devia ser fácil e generalizada a aceitação de um médico que se dedicasse ao assunto. Tentando se desvincular do neomalthusianismo, ele esclarece que está do lado da moral, da religião e da ciência. Em função disso é que se salvaguarda em citações de mestres famosos. O autor cita o pronunciamento do professor Fraenkel na Sociedade Alemã de Ginecologia, no qual se defende que o médico não pode se manter à margem de tão relevante questão, tendo o dever de ensinar às mulheres os meios eficazes de evitar a gravidez. Não só no terreno da doença, mas também no da contracepção, a missão do ginecologista é "evitar desastres e praticar o bem" (Azevedo, 1936). A posição do médico alemão é ponderada pelo dr. Arnaldo de Moraes, catedrático de ginecologia e uma autoridade no assunto. Moraes afirmava que a ética médica e as leis do país não autorizavam o médico a ensinar as práticas anticoncepcionais. Mas nos casos em que houvesse indicação científica, ou a seu critério clínico, o médico deveria não só dizer ao casal que evitasse a gravidez, mas também ensinar os métodos eficazes e não prejudiciais (apud Azevedo, 1936:477). Nota-se que há, por um lado, uma investida na justificação da anticoncepção e, por outro, uma tentativa de restringir o seu controle ao médico, que não apenas teria a posse dos meios de intervenção, mas julgaria os casos em questão. 
No que se refere às tais indicações científicas, Azevedo recorre ao que foi proposto nas Jornadas Eugênicas Espanholas. As indicações são as seguintes:

$1^{\circ}$ ) Indicação eugênica - Quando os pais sofrem doenças transmissíveis aos filhos por herança ou congenitamente.

$2^{\circ}$ ) Indicação social ou econômica - Quando a sua situação econômica não lhes permite criar e educar os filhos por nascer.

$\left.3^{\circ}\right)$ Indicação médica - Quando a saúde da mulher periga com a concepção.

$4^{\circ}$ ) Indicação sentimental - Quando existe o desejo de não ter filhos. (Azevedo, 1936:477-478)

Apesar de citar essas indicações, bastante abrangentes, Azevedo prefere se abster de comentá-las. Diz que não é o momento oportuno. Contudo, a opção por não tratar do assunto não estaria relacionada a algum tipo de pudor quanto à eugenia, já que ele reafirma a idéia de que o método de Ogino-Knaus deve ser empregado sempre que "razões de índole médica ou eugênica aconselhem a esterilização provisória ou definitiva" (Azevedo, 1936:48). Prefere falar dos casos que ele mesmo tratou e nos quais jamais imperaram motivos fúteis ou inconfessáveis. Afirma que as indicações implicadas nos seus casos foram: multiparidade, passado obstétrico acidentado (cesarianas), práticas anticoncepcionais artificiais e abortos criminosos. Ora, diante dessas indicações também tão amplas e de naturezas distintas, desde razões obstétricas até o uso de meios artificiais e a prática do aborto, torna-se difícil entender a recusa do autor em comentar as propostas dos médicos espanhóis. Também se percebe que, sob o rótulo de indicação científica, muitas práticas realizadas anteriormente pelo casal e consideradas condenáveis moralmente constituem razões válidas para a anticoncepção sob orientação do médico. O que estaria em jogo seria a tentativa de combater a continuação do uso destes meios transformando o controle da natalidade em assunto médico. A lógica de combater um mal maior (práticas neomalthusianas e aborto criminoso) por um menor (continência periódica) tornava-se predominante. É nesse sentido que Azevedo explica as 'indicações' referentes ao abuso dos meios neomalthusianos e do aborto criminoso.

Quanto aos meios neomalthusianos, apóia-se nas declarações de Van de Velde e de Fraenkel, que considera as maiores autoridades no assunto. 
O primeiro denuncia a existência de mais de 150 meios anticoncepcionais, cujo emprego seria sempre acompanhado de moléstias físicas e mentais e transtornos. O condom, por exemplo, causaria irritação inflamatória da vulva e da vagina na mulher e da glande no homem, além de incômodos para um ambiente matrimonial feliz. Entre as moléstias causadas também se encontrava o "síndroma de carência espermática":

O abuso do coito interrompido e do coito condomatoso criou uma nova entidade nosológica - o síndroma de carência espermática, cujos principais sintomas se resumem em perturbações menstruais, nervosismo, tendência melancólica e ansiosa, que se exacerbam nos dias consecutivos às relações fraudulentas e que se atenuam ou desaparecem sob a ação do extrato espermático associada à supressão ou à modificação das práticas preventivas.

A carência espermática é a principal causa das perturbações nervosas e psíquicas freqüentemente encontradas nos casos de esterilidade voluntária. (Azevedo, 1936:480)

A influência que a falta da absorção espermática exerceria sobre as perturbações físicas e mentais femininas aparecia em diversos autores e em algumas discussões em congressos. Quando a causa dos males era diagnosticada, recorria-se freqüentemente à "opoterapia heterossexual" (emprego de fluídos do sexo oposto). Mas, o "síndroma das fraudadoras" começou a ser melhor tratado a partir do momento que, em função do método de Ogino-Knaus, passou-se a fazer a impregnação espermática direta na mulher, no período não fértil. Apenas dois coitos completos já seriam suficientes para uma melhora acentuada dos sintomas de nervosismo e para uma rápida regularização do fluxo menstrual. Azevedo ainda acrescenta que no homem o ato sexual termina com o orgasmo. Porém, na mulher, ele será sempre incompleto quando não terminar na absorção das substâncias do líquido seminal que utiliza para seu equilíbrio fisio-psicológico. $O$ autor pretende respaldar suas afirmações na psicanálise, dizendo que Freud teria revelado a influência preponderante do ato sexual incompleto e artificial na gênese de numerosos distúrbios psíquicos. Além disso, sustenta que o instinto da maternidade faz parte integrante da psique feminina. O receio da gravidez entraria em conflito com esse instinto, recalcandoo no subconsciente e exteriorizando-o sob a forma de 'obsessões', 'idéias negras' e 'delírios'. Se a mulher fosse católica, seria ainda mais torturada pelos conflitos religiosos e morais (Azevedo, 1936:481). 
O método da continência periódica, que permite a realização completa e natural do ato sexual e concilia os preceitos morais e religiosos, viria restituir a saúde e a paz dessas mulheres. Azevedo relata o caso de uma paciente sua, profundamente religiosa, que jazia em um estado de acentuada psicose, com alucinações e visões e outros indicadores de abalo físico, relacionados à culpa que sentia pelo uso de métodos artificiais de anticoncepção, e que se restabeleceu com o método de Ogino-Knaus. O autor ainda diz:

Outros casos observamos de perturbações orgânicas ou de transtornos psíquicos, de síndromas de carência espermática ou de complexos e recalcamentos freudianos, em que o repúdio das práticas anticoncepcionais artificiais e a aplicação de métodos de continência periódica redundaram sempre em uma transmutação completa do corpo e do espírito das nossas pacientes. (Azevedo, 1936:482)

Azevedo afirma que se deve preferir o método de Ogino-Knaus à esterilização sempre que se revele que o ato sexual incompleto está na raiz dos distúrbios mentais. Os processos de esterilização poderiam agravar o estado psíquico e só deveriam ser aplicados nos casos em que, esgotados todos os recursos, já não houvesse esperança para o restabelecimento mental.

Ao lado das perturbações nervosas, os meios neomalthusianos também provocariam perturbações e afecções orgânicas no aparelho genital feminino, constituindo uma verdadeira 'patologia anticoncepcional'. O coito interrompido ou condomatoso teria como consequências: dores lombares e hipogástricas, fadiga dos membros inferiores, dor no momento da defecação, dores ao menor esforço e movimento acentuadas durante o ato sexual, frigidez e aversão à vida conjugal, mudanças de caráter, irritabilidade, irascibilidade, emotividade, tristeza, falta de energia e de coragem, perturbações digestivas, inapetência, digestões laboriosas, constipação, cefalgias e idéias de suicídio. Além disso, o exame ginecológico ainda revelaria sinais de metrite e parametrite, congestão pelviana, inflamação e hiperplasia, esclerose dos ovários, tumores, fibromas, quistos, predisposição ao câncer e perturbações no ritmo menstrual. E, por fim, se poderia chegar à esterilidade temporária ou definitiva que "a natureza revoltada impõe à mulher que calculadamente fugiu aos encargos da maternidade" (Azevedo, 1936:483).

Além disso, esses meios criariam uma situação penosa para o casal, impedindo a entrega inconsciente que deveria existir durante os 'contatos 
genésicos'. Azevedo cita também Mary Stopes, uma ardorosa propagadora do neomalthusianismo, que reconhecia a falibilidade da maioria dos anticoncepcionais e confessava os malefícios que o uso do pessário vaginal poderia trazer, especialmente as perturbações da libido. ${ }^{17}$ Segundo o autor, o fato de os próprios adeptos do neomalthusianismo reconhecerem a ineficiência de seus métodos contribuiria para a justa valorização do método de Ogino-Knaus (Azevedo, 1936:478-480).

A abstinência temporária, segundo Azevedo, apresentava-se como um verdadeiro antídoto para os danos que vinham produzindo os métodos antinaturais de profilaxia da concepção. Também seria a melhor arma no combate à prática do aborto. $\mathrm{O}$ autor conta que em suas observações estão casos de mulheres de elevada camada social que chegaram a confessar a realização de mais de 15 abortos em um curto prazo. Arnaldo de Moraes teria dito que a prática anticoncepcional e o aborto criminoso constituiriam entre nós uma verdadeira indústria. Já Fernando Magalhães chegou a apresentar dados da sua freqüência assustadora. Segundo esse médico, 70\% das quatro mil mulheres que atendeu em seu consultório confessaram que já haviam feito aborto por 'motivos inferiores'. Os dados de Magalhães e Azevedo e de outros médicos parecem mostrar como era significativa a prática do aborto também em mulheres de camadas mais favorecidas.

Azevedo termina o seu artigo dizendo que, infelizmente, no Brasil, os anúncios de prática de aborto disfarçados apareciam cada vez mais e impunemente. Enquanto isso, o método da continência periódica, que tem todas as garantias científicas, morais e religiosas, às vezes é confundido com práticas condenáveis. O autor diz que ele mesmo já sofreu o dissabor de ver sua técnica malevolamente interpretada, apesar das suas mais puras intenções. A raiz do problema estaria no Código Penal, que não distinguia a anticoncepção do aborto: "O nosso código, deficiente e bolorento, não permite o precocínio de um método científico, moral e religiosamente inatacável, de regularização da concepção, mas admite o anúncio disfarçado da prática indecorosa do aborto criminoso" (Azevedo, 1936:486). Apoiado em Afranio Peixoto, conclui dizendo que a contracepção é um mal necessário diante da necessidade de pôr fim ao aborto criminoso, mas tem sido prejudicada pelas próprias leis do país, que percebem como semelhantes práticas de natureza tão diversa.

O tema da contracepção aparece outras vezes nos Annaes Brasileiros de Gynecologia. Ainda em 1936, há uma resenha elogiosa do livro lançado 
por Azevedo, denominado Maternidade Consciente. A revista apresenta a publicação como "o único trabalho nacional de fôlego" e endossa suas posições, já vistas no artigo apresentado anteriormente (Annaes Brasileiros de Gynecologia, 1936:491). No mesmo ano, outra resenha tratava da obra de Carijó Cerejo, intitulada Anticoncepção. Segundo o resumo, tratava-se de uma brochura para leigos que considerava vários aspectos envolvendo a prevenção da gravidez de forma correta e moderna, o que significava na prática o privilégio ao método de Ogino-Knaus e a condenação do aborto (Annaes Brasileiros de Gynecologia, 1936:214). As resenhas incluíam também trabalhos internacionais.

Em 1937, comenta-se o artigo Indications for contraception from the point of view of the obstetrician and gynecologist, de Montgomery, publicado nos Estados Unidos. O trabalho defende que, quando a gravidez constitui uma ameaça à saúde da paciente, e só neste caso, algum meio anticoncepcional deve ser prescrito pelo médico. O autor condena as técnicas anticoncepcionais utilizadas e, quando a indicação é de natureza permanente, prefere o recurso à histerectomia e à esterilização. Afirma que entre a população feminina vinha crescendo a exigência pela maior amplitude das práticas anticoncepcionais, o que colocava o obstetra em uma posição difícil. Diz que o médico deveria participar na discussão a respeito da anticoncepção como solução para o pauperismo. E termina concluindo que se vinha esperando demasiadamente que a anticoncepção contribuísse como um instrumento de aperfeiçoamento da raça. No seu entender, a propaganda destinada a elevar a posição da maternidade e a exaltar os prazeres da vida em família faria muito mais pelo aumento da reprodução nas classes mais altas (Annaes Brasileiros de Gynecologia, 1937:255-257).

Percebe-se na resenha que um dos pontos fundamentais através do qual a contracepção era discutida referia-se ao seu valor como meio de evitar a propagação de seres que contribuiriam para o enfraquecimento da raça. Paralelamente, nota-se que o aperfeiçoamento da raça estava condicionado ao aumento da natalidade nas classes mais altas. Ou seja, havia lugar para um certo deslizamento entre a noção de raça e de classe. Os mais pobres, por uma série de circunstâncias, eram mais responsáveis pela reprodução de degenerados, enquanto os mais ricos contribuíam para a realização do projeto eugênico. Note-se também a idéia, expressa pelo autor, de que é necessário propagandear a maternidade. Essa concepção, comum nos Estados Unidos e na Europa, aparece também na resenha ao 
trabalho Sobre el aborto voluntário, de Juan Gabaiton, publicado em Buenos Aires. O autor afirma que é somente o sentimento da maternidade, reafirmado na mulher desde a mais tenra infância, que poderia preservar a humanidade, e não as imposições do Estado, da sociedade ou da Igreja. Caberia ao médico, que conhece as deficiências físicas e os males morais das mulheres, o melhor julgamento a respeito das questões relativas ao controle da natalidade e o recurso ao método de Ogino-Knaus, em detrimento da prática do aborto (Annaes Brasileiros de Gynecologia, 1938:216-217). Em 1939, outra resenha ao artigo do americano Kosmak conclamava os médicos a se envolverem mais com o problema da restrição da natalidade em função das exigências sociais do momento (Annaes Brasileiros de Gynecologia, 1939:365).

Da intrincada relação entre eugenia, contracepção e maternidade, é necessário fazer alguns comentários. Em primeiro lugar, há uma constante afirmação de que o médico, ao lado dos legisladores, deve tomar a frente no estudo e controle das questões relacionadas à reprodução, especialmente no que tange ao controle da natalidade. Anteriormente, a reprodução já tinha se tornado uma área de grande investimento médico, mas a contracepção, pelo menos publicamente, parecia ser um assunto suficientemente imoral para que os médicos não se dignassem a considerá-lo. Através da propagação das idéias eugênicas, sempre revestidas e resguardadas pelo caráter científico, o tema da contracepção passa a ser reconsiderado. Recorrendo às teses da Faculdade de Medicina do Rio de Janeiro, percebe-se que os raros trabalhos que falam em anticoncepção estão associadas à eugenia. ${ }^{18} \mathrm{~A}$ partir da vontade de coibir o nascimento de indivíduos 'indesejáveis', até mesmo a esterilização é defendida como um meio legítimo. Mas, com relação aos indivíduos considerados 'normais', a questão é outra. A julgar pela posição de Azevedo (1936), poder-se-ia até admitir a contracepção, exclusivamente através do método de Ogino-Knaus, que não é visto como imoral, mas desde que haja uma indicação científica para o caso. Entretanto, em termos gerais, para os casais 'saudáveis', o que parece imperar é a lei da procriação. Para esses, todas as formas de controle da natalidade, desde as práticas neomalthusianas até o aborto, são condenadas. E longe de se prever a contracepção, prega-se a valorização da maternidade e da vida familiar. ${ }^{19}$

Contudo, é interessante que os próprios médicos admitam que há uma pressão social - e alguns dizem que é mais forte entre as mulheres para a propagação da contracepção. E é em função dessa pressão que os 
doutores se dizem convocados a reagir. Sua resposta vem na forma de um projeto de valorização da maternidade que passa pela propaganda em prol da natalidade, especialmente frente às mulheres. Diante do panorama instalado pela eugenia e pelo nacionalismo, que via o número de cidadãos como garantia de soberania, era preciso convencer as mulheres sadias da importância do seu papel de mães. Era preciso recuperar em seus espíritos, talvez abalados pelo excesso de civilização, educação e trabalho, o instinto materno. E também era preciso melhorar a capacidade de ser mãe de acordo com os princípios da eugenia, da higiene e da puericultura.

\section{Notas}

1 Souza Lima pondera, interpretando aquele Código, que a mulher dificilmente poderia ser considerada criminosa, pois na legislação brasileira ela nunca era responsabilizada por seus atos (Revista Syniatrica, 1915).

2 Leonídio Ribeiro menciona que esse trabalho é uma reimpressão do artigo publicado na Folha Medica de 25 de maio de 1930.

3 Corrêa (1998) menciona que ainda em 1931, e depois em 1938, Leonídio Ribeiro se envolveria em discussões sobre o aborto, argumentando em prol da proteção das famílias e das vantagens do aumento da população.

4 Na sessão de 26 de agosto, Fernando Magalhães protesta contra a redação do boletim da Academia de Medicina que resume os fatos passados nas reuniões. Afirma que parte do seu discurso foi suprimida. Miguel Couto responde que nem sempre a redação encerra com perfeição tudo o que se passou nas sessões e Belmiro Valverde, redator do documento, diz que assim procedeu em nome do decoro da casa. A nomeação de uma comissão para discutir a atribuição dos redatores gera novas discussões e o descontentamento de Magalhães faz com que peça demissão do cargo de Presidente da Seção de Cirurgia Especializada que ocupava (Brazil Medico, 1920).

5 Essa observação não se restringe aos trabalhos mais antigos. Em 1982, os médicos autores do livro Aborto: o direito à vida, estudo laureado pela Academia Nacional de Medicina, condenavam a anticoncepção de forma generalizada e relacionavam-na ao aborto: "Práticas anti-humanas - como o abortamento, o anticoncepcionalismo etc. - que diminuem o valor da vida humana e desfiguram a família, constituem-se em fatores de corrupção e degradação da sociedade que as institucionaliza" (Alves et al., 1982:38). "A formação de uma mentalidade anticoncepcional, má em si mesma, também o é como estágio intermediário e necessário para se chegar à tolerância e depois à plena aceitação do abortamento como coisa 'normal'" (Alves et al., 1982:39).

6 Para essa comissão foram nomeados os doutores Mello Teixeira, Pimenta Bueno e Leontino Cunha (Brazil Medico, 1920). Não cheguei a encontrar outras referências sobre essa comissão e o resultado de seus estudos. 
7 Em consonância com o desejo destes médicos, a Lei das Contravenções Penais (Decreto-Lei ne 3.688, de 3 de outubro de 1941) incluiria a punição daqueles que anunciassem meios abortivos ou anticoncepcionais: "Art. 20 - Anunciar processo, substância ou objeto destinado a provocar aborto ou evitar a gravidez; Pena - multa de quinhentos mil réis a cinco mil contos de réis" (Revista Forense, 1941, 88:609).

8 A análise que segue introduz a questão da eugenia a partir do que aparece nos trabalhos médicos relativos à sexualidade e reprodução. Não pretendo me deter sobre a eugenia enquanto um movimento mais abrangente, que mereceria um estudo bem mais cuidadoso, como o realizado por Stepan (1990). Para um panorama geral do desenvolvimento das idéias eugênicas em diversos contextos nacionais, ver Schneider (1982), Adams (1990) e Carol (1995).

9 Essa revista perdurou pelo menos até 1969.

1 Essa cátedra era ocupada na época por Arnaldo de Moraes.

"Stepan (1990) menciona que na década de 1930 há uma maior aproximação dos eugenistas brasileiros com os autores alemães, o que ajuda a entender esta referência dos ginecologistas à produção científica alemã e ao modelo eugênico em curso naquele país.

n Somente no primeiro número, constavam artigos das seguintes publicações: Gynecologie et Obstetrique; Revue Française de Gynecologie; Bulletin de la Societé d'Obstetrique et de Gynecologie de Paris; Surgery, Gynecology and Obstetrics; American Journal of Obstetrics and Gynecology; The Journal of the American Medical Association; The British Medical Journal; Zentralblatt für Gynäkologie; Archiv für Gynäkologie; Boletín de la Sociedad de Obstetricia y Ginecología de Buenos Aires; Revista de Obstetrícia e Ginecologia de São Paulo; Revista Brasileira de Cirurgia; Revista de Ginecologia e Obstetrícia.

13 Stepan (1990) menciona que, apesar do eugenismo brasileiro enfatizar mais a prevenção, temas característicos da eugenia 'negativa', como o aborto, o controle da natalidade e a esterilização também estiveram em pauta. Mas, no Brasil, a influência do catolicismo e a preocupação com a natalidade fizeram com que o movimento tomasse outra direção. Borges (1991) também fala sobre a importância da Igreja na conformação de uma eugenia brasileira menos afeita a programas de intervenção radical, como a esterilização, por exemplo. Vale lembrar que em 1930 a encíclica Casti Connubii condenava o controle da natalidade, esterilizacão e aborto eugênicos.

1 Entre essas doenças estavam a imbecilidade hereditária, a esquizofrenia, a loucura maníaco-depressiva, a epilepsia hereditária, a cegueira hereditária, a surdez hereditária, a grave deformação hereditária e o alcoolismo grave. Seriam dispensadas as mulheres que apresentassem a falta congênita da vagina ou do útero, perturbações hormonais graves, amenorréia permanente com hipoplasia do útero, oclusão bilateral das trompas e idade acima de 45 anos (Annaes Brasileiros de Gynecologia, 1936, v. II:228-231).

15 Somente no primeiro ano de vigência da lei, em 1934, foram feitos 84.525 requerimentos de esterilização, dos quais 42.903 referentes a homens e 41.663 referentes a mulheres. Dos 64.449 pedidos julgados até 31 de dezembro do mesmo ano, tinham sido aprovados 56.224 e reprovados 3.692 (Annaes Brasileiros de Gynecologia, 1936).

16 Azevedo era assistente da Clínica Obstétrica da Universidade do Rio de Janeiro, do Serviço de Cirurgia e Ginecologia da Beneficência Portuguesa e da Pró-Matre. 
17 Sobre a posição de Mary Stopes e outras feministas nas campanhas pelo controle da natalidade, ver McLaren (1990).

1s É o caso do seguintes trabalhos: Mello (1911), Vilhena (1919) e Ligiero (1930).

19 Bock (1983), trabalhando sobre a conexão entre racismo e sexismo nas concepções e práticas nazistas envolvendo maternidade e esterilização compulsória, afirma que, enquanto se propunha o incentivo à maternidade de muitas mulheres, impunha-se a esterilização a outras. As primeiras eram as consideradas racial e hereditariamente puras. As segundas, ameaças à nação e à raça alemã. O pró-natalismo para os desejáveis e o antinatalismo para os indesejáveis estão intrinsecamente conectados. As leis que proíbem o aborto e a esterilização voluntária são concomitantes às que legalizam o aborto e esterilização eugênicos. A autora sugere que estes acontecimentos estão relacionados com o fato de que o discurso da higiene da raça, muito mais do que outras teorias, desde o fim do século XIX concede uma importância fundamental à mulher, seja como a 'mãe da raça', seja como culpada pela degeneração racial. $O$ eugenismo parece especialmente preocupado com os domínios supostamente naturais ou biológicos aos quais a mulher parece mais associada, como o corpo, a sexualidade, a procriação. Além disso, também era preciso reafirmar que o destino natural das mulheres era serem esposas e mães frente às tentativas de emancipação e de redução do número de filhos, tão importante para o Estado naquele momento. Sobre sexo, reprodução, contracepção, aborto e esterilização na Alemanha desse período, vale recorrer também a Grossmann (1995). 